\title{
Deskripsi Kemampuan Komunikasi Matematis Ditinjau dari Disposisi Matematis Siswa SMP
}

\author{
Nurdin Arsyad $^{1, \text { a) }}$, Asdar $^{1, \text { b) }}$, dan Musfira Ramadhani ${ }^{1, c)}$ \\ ${ }^{1}$ Jurusan Matematika, Fakultas MIPA, Universitas Negeri Makassar \\ a)nurdin.arsyad@unm.ac.id \\ b) asdar.ahmad@unm.ac.id \\ c)musfira2501@gmail.com
}

\begin{abstract}
Abstrak. Penelitian ini merupakan penelitian kualitatif dengan pendekatan deskriptif, bertujuan untuk mengidentifikasi kemampuan komunikasi matematis berdasarkan disposisi matematis pada materi persamaan garis lurus. Subjek penelitian ini ialah siswa kelas VIII yang mewakili setiap kategori disposisi matematis yaitu tinggi, sedang, dan rendah. Teknik pengumpulan data dilakukan dengan pemberian angket, tes, dan wawancara. Hasil penelitian menunjukkan bahwa seluruh siswa pada setiap kategori disposisi maтри menuliskan solusi secara sistematis dan mampu menggunakan simbol matematika dengan tepat. Namun, siswa DMR kurang mampu memahami masalah sehingga terdapat kekeliruan penyelesaian. Perbedaan kemampuan siswa terlihat dari kemampuan menggambarkan grafik. Siswa DMT menggambarkan grafik dengan tepat. Sedangkan, siswa DMS menggambarkan grafik yang kurang tepat. Adapun, siswa DMR tidak mampu menggambarkan grafik solusi dari soal.
\end{abstract}

Kata Kunci: Kemampuan, Komunikasi Matematis, Disposisi Matematis, Persaman Garis Lurus

\begin{abstract}
This research is qualitative research with a descriptive approach, aiming to identify mathematical communication skills based on mathematical disposition in straight-line equation matter. The subject of this research are students of class VIII who represent each category of mathematical disposition that is high, medium, and low. Data collection techniques are done by giving questioner, tests, and interviews. The results showed that all students in each disposition category were able to write solutions systematically and were able to use mathematical symbols appropriately. However, DMR students are less able to understand the problem so there is a mistake in solving it. The difference in students' abilities can be seen from the ability to graph. DMT students draw graphs precisely. Meanwhile, DMS students draw inappropriate graphs. As for the subject, DMR students are not able to draw a solution graph of the problem.
\end{abstract}

Keywords: Ability, Mathematical Communication, Mathematical Disposition, Straight Line Equation 


\section{PENDAHULUAN}

Kemampuan komunikasi matematis merupakan salah satu kemampuan dasar yang diharapkan siswa miliki dalam proses pembelajaran matematika. Menurut Wijaya, Sujadi, dan Riyadi (2016) komunikasi matematis adalah cara bagi siswa untuk mengkomunikasikan ide pemecahan masalah, strategi atau solusi baik melalui tulisan maupun lisan. Adapun menurut Bistari (2010) kemampuan komunikasi matematis merupakan kemampuan siswa untuk menjelaskan, mengkonstruksi dan menyajikan fenomena nyata melalui grafik, kata-kata, persamaan, tabel, dan lain-lain.

Kemampuan komunikasi matematis siswa dapat dikembangkan dengan melibatkan siswa secara aktif dalam proses pembelajaran. Simamora (2017) menyebutkan terdapat beberapa aktivitas yang dapat dilakukan untuk mengembangkan kemampuan komunikasi matematis siswa yaitu mengarahkan siswa untuk mengumpulkan informasi dari berbagai sumber untuk memikirkan ide awal. Misalnya, siswa dapat berdiskusi dengan teman, bertanya pada guru, maupun membaca buku. Selain itu, siswa juga dilatih untuk menyampaikan hasil penyelesaian atau pemikirannya baik secara lisan maupun tulisan. Dengan berbagai aktivitas tersebut diharapkan kemampuan komunikasi matematis siswa dapat berkembang, sehingga berdampak pula pada prestasi belajar matematika siswa.

Kemampuan komunikasi matematis yang dimiliki setiap siswa berbeda-beda. Hikmawati, Nurcahyono, dan Balkist (2019) menyebutkan bahwa faktor yang mempengaruhi kemampuan komunikasi matematis siswa antara lain; pemahaman siswa, kebiasaan, proses pembelajaran, dan sikap. Selain beberapa faktor tersebut, faktor lain yang mampu mempengaruhi kemampuan komunikasi matematis adalah disposisi matematis (Diningrum, Azhar, dan Faradhillah; 2018).

Disposisi matematis adalah keinginan, kesadaran, dedikasi, kecenderungan yang kuat pada diri siswa untuk berpikir, dan berbuat secara matematis dengan cara positif dan didasari dengan iman, taqwa, dan akhlak mulia (Sumarmo, 2011). Adapun dalam penelitian yang dilakukan oleh Mandur, Sandra, dan Suparta (2013), disposisi matematis berupa sikap bersungguh-sungguh atau rasa tanggung jawab yang dimiliki siswa dalam menyelesaikan tugas matematika.

Baik kemampuan komunikasi matematis maupun disposisi matematis, keduanya mampu meningkatkan prestasi belajar matematika siswa. Hal tersebut didasarkan pada penelitian yang telah dilakukan beberapa orang yang menyatakan semakin tinggi kemampuan komunikasi matematis maka semakin tinggi pula prestasi belajar matematika siswa (Astuti \& Leonard, 2012; Afiani, 2016; Ocktaviani, Aulia, \& Zanthy, 2019). Tak berbeda dengan kemampuan komunikasi matematis, disposisi matematis juga memberikan pengaruh yang positif terhadap prestasi belajar (Mandur, dkk, 2013; Nurhaja \& Suhar; 2015; Annajmi, 2018). Oleh karena itu, penting untuk mengetahui hubungan antara kemampuan komunikasi matematis dan dipsosisi matematis dalam pembelajaran matematika.

Penelitian ini mengidentifikasi kemampuan komunikasi matematis siswa. Kemampuan komunikasi matematis siswa yang diungkapkan berupa kemampuan komunikasi matematis secara tertulis, dan dideskripsikan berdasarkan tingkat disposisi matematis siswa. Adapun, tujuan penelitian ini yaitu mendeskripsikan kemampuan komunikasi matematis siswa ditinjau dari disposisi matematis pada materi persamaan garis lurus. 


\section{KAJIAN PUSTAKA}

\section{Komunikasi Matematis}

Komunikasi matematis merupakan suatu cara yang dilakukan untuk memberikan gambaran ide guna memperjelas pemahaman matematika (NCTM, 2000). Melalui kemampuan komunikasi matematis, siswa dapat saling bertukar pikiran, dan sekaligus mengklarifikasi pemahaman dan pengetahuan yang mereka peroleh dalam pembelajaran (Hodiyanto, 2017).

Komunikasi dalam pembelajaran matematika terdiri dari 2 jenis yaitu komunikasi lisan dan komunikasi tulisan. Komunikasi secara lisan dalam pembelajaran dapat dilihat dari sikap siswa saat berdiskusi, mengajukan pertanyaan, dan menjelaskan pemikirannya atau jawabannya. Sedangkan, komunikasi secara tulisan dapat dilihat dari kemampuan siswa membuat penyelesaian menggunakan simbol-simbol matematika sesuai dengan apa yang dipikirkan untuk menyelesaikan masalah yang diberikan.

Wijaya, dkk (2016) berpendapat bahwa kemampuan komunikasi matematis merupakan suatu kemampuan yang perlu siswa miliki dengan indikator:

1. Kemampuan mengekspresikan ide-ide matematika melalui lisan, tulisan, dan mendemonstrasikannya dan menggambarkannya secara visual,

2. Kemampuan memahami, menginterpretasikan, dan mengevaluasi ide-ide matematika baik secara lisan maupun dalam bentuk visual lainnnya, dan

3. Kemampuan untuk menggunakan istilah-istilah, notasi-notasi matematika dan strukturnya untuk menyajikan ide, mengambarkan hubungan dan model-model situasi.

Adapun indikator kemampuan komunikasi matematis dalam penelitian ini, sebagai berikut;

1. Memahami dan menuliskan solusi dari suatu permasalahan dengan bahasa sendiri.

Kemampuan siswa untuk mengidentifikasi informasi yang terdapat pada soal yang digunakan untuk menemukan solusi yang tepat. Selain itu, terlihat pula kemampuan siswa dalam menuliskan solusi yang lengkap dan tepat.

2. Menjelaskan solusi dalam bentuk gambar.

Kemampuan siswa dalam memberikan solusi berupa gambar atau grafik. Selain itu, terlihat pula kemampuan siswa dalam memberikan penjelasan terkait grafik yang digambarkan.

3. Menggunakan simbol matematika yang tepat.

Kemampuan siswa dalam menggunakan simbol matematika untuk menyatakan suatu hal atau data.

Melalui kemampuan komunikasi matematis siswa dapat meningkatkan prestasi belajar matematika. Hal ini berdasarkan penelitian yang dilakukan oleh Afiani (2016) yang mengatakan bahwa terdapat pengaruh komunikasi matemtis terhadap prestasi belajar. Selain itu, Ocktaviani, dkk (2019) juga menyatakan adanya peningkatan pada kemampuan komunikasi matematis akan diiringi dengan meningkatnya keberhasilan belajar matematika siswa.

\section{Disposisi Matematis}

Prestasi belajar matematika dapat ditingkatkan dengan mengembangkan faktor-faktor selain kemampuan pemahaman siswa. Penelitian yang dilakukan oleh Annajmi (2018) menyatakan bahwa selain minat dan kecerdasan, disposisi matematis juga memberikan pengaruh positif terhadap prestasi belajar matematika. Sejalan dengan hal tersebut, Diningrum, dkk (2018) menyatakan bahwa disposisi matematis juga memberikan perngaruh untuk mengembangkan kemampuan matematis siswa, yang nantinya akan berdampak pada prestasi belajar matematika siswa yang meningkat.

Disposisi matematis adalah keinginan, kesadaran, dedikasi, kecenderungan yang kuat pada diri siswa untuk berpikir, dan berbuat secara matematis dengan cara positif dan didasari dengan 
iman, taqwa, dan akhlak mulia (Sumarmo, 2011). Selain itu, disposisi matematis juga didefinisikan sebagai keinginan, kesadaran, dan dedikasi yang kuat pada diri siswa untuk belajar matematika dan melaksanakan berbagai kegiatan matematika (Andiani, 2016).

Pada proses pembelajaran matematika, disposisi matematis akan memberikan gambaran mengenai bagaimana siswa menyelesaikan permasalahan, bertanya, menyampaikan pertanyaan, merepresentasikan pemikirannya terkait solusi permasalahan, dan bekerja secara berkelompok. Menurut Mahmudi (2010), sikap yang menjadi tolak ukur kemampuan disposisi matematis, antara lain: (1) percaya diri; kemampuan siswa untuk mengutarakan pendapatnya, (2) gigih atau ketekunan dalam mengerjakan tugas matematika, (3) berpikir terbuka atau fleksibel; siswa mampu menerima pendapat orang lain, (4) memiliki minat dan keingintahuan dalam belajar matematika, dan (5) monitor dan mengevaluasi.

\section{METODE PENELITIAN}

Penelitian ini merupakan penelitian kualitatif dengan pendekatan deskripsi. Penelitian ini menggambarkan kemampuan komunikasi matematis siswa ditinjau dari disposisi matematis. Subjek dalam penelitian ini merupakan 3 orang siswa kelas VIII dengan tingkat disposisi matematis yang berbeda-beda.

Pengumpulan data penelitian dilakukan dengan beberapa metode yaitu metode angket, tes, dan wawancara. Metode angket digunakan untuk mengelompokkan siswa berdasarkan tingkat disposisi matematis, metode tes digunakan untuk mengetahui kemampuan komunikasi matematis siswa yang menjadi siswa penelitian, dan metode wawancara yang dilakukan untuk mengungkapkan kemampuan komunikasi matematis siswa berdasarkan hasil tes kemampuan komunikasi matematis pada materi persamaan garis lurus. Berdasarkan metode yang dilakukan, instrumen yang digunakan pada penelitian ini berupa angket disposisi matematis, tes kemampuan komunikasi matematis dan pedoman wawancara yang telah divalidasi oleh dua orang ahli.

TABEL 1. Kategori Disposisi Matematis

\begin{tabular}{cc}
\hline Interval & Kategori \\
\hline Skor $\geq 80$ & Tinggi \\
$70 \leq$ Skor $<80$ & Sedang \\
Skor $<70$ & Rendah \\
\hline
\end{tabular}

Pengambilan data dilakukan dengan cara menggolongkan siswa berdasarkan hasil perolehan skor angket disposisi matematis. Siswa digolongkan ke beberapa kategori sesuai dengan pengkategorian disposisi matematis pada Tabel 1. Selanjutnya, dipilih 3 orang siswa sebagai siswa penelitian yaitu 1 siswa dengan disposisi matematis tinggi, 1 siswa dengan disposisi matematis sedang, dan 1 siswa dengan disposisi matematis rendah. Langkah selanjutnya yang dilakukan yaitu memeriksa hasil tes untuk mengidentifikasi kemampuan komunikasi matematis setiap siswa. Untuk menganalisa kemampuan komunikasi matematis secara mendalam selanjutnya dilakukan wawancara. Kemudian, berdasarkan data hasil tes dan wawancara disajikan data berupa deskripsi kemampuan komunikasi matematis setiap siswa.

\section{PEMBAHASAN}

Pada bab ini dijelaskan mengenai hasil penelitian yang didasarkan pada analisis jawaban siswa dalam menyelesaikan soal persamaan garis lurus. Berdasarkan hasil penelitian dibahas mengenai kemampuan komunikasi matematis masing-masing siswa, sebagai berikut: 


\section{Siswa dengan disposisi matematis tinggi (DMT)}

Berikut disajikan hasil tes dan wawancara siswa DMT yang didasarkan pada indikator-indikator kemampuan komunikasi matematis siswa.

1. Memahami dan menuliskan solusi permasalahan

\section{Penyelesaian :}

$$
\text { a. } \begin{aligned}
& \frac{y \cdot y_{1}}{y_{2}-y_{1}}=\frac{x-x_{1}}{x_{2}-x_{1}} \\
& \frac{y-1}{3-1}=\frac{x-3}{25-3} \\
& =\frac{y-1}{2}=\frac{x-3}{22} \\
& =22(y-1)=2(x-3) \\
& 22 y-22=2 x-6 \\
& 22 y-2 x=22-6 \\
& 22 y-2 x=16 \\
& 22 y-2 x-6
\end{aligned}
$$

GAMBAR 1 Hasil tes siswa DMT

Pada Gambar 1 terlihat siswa menggunakan rumus $\frac{y-y_{1}}{y_{2}-y_{1}}=\frac{x-x_{1}}{x_{2}-x_{1}}$ untuk menentukan persamaan garis lurus. Selanjutnya, siswa mensubstitusi data yaitu $3,25,1$, dan 3 masing-masing ke variabel $x_{1}, x_{2}, y_{1}$, dan $y_{2}$. Langkah-langkah penyelesaian yang dilakukan oleh siswa sudah tepat dan tidak terdapat kesalahan dalam perhitungan. Penjelasan siswa mengenai tahapan penyelesaian dapat dilihat pada Transkrip 1.

\section{TRANSKRIP 1}

$$
\begin{aligned}
& P-003 \quad \text { : Kalau bagaian a kan yang ditanyakan persamaan, bagaimana } \\
& \text { diselesaikan itu? } \\
& \text { Untuk menyelesaikan bagian a itu menggunakan persamaan garis } \\
& \text { DMT-003 : lurus yaitu: } \frac{y-y_{1}}{y_{2}-y_{1}}=\frac{x-x_{1}}{x_{2}-x_{1}} \\
& P-004 \quad: \quad \text { Kenapa ki pakai rumus ini? } \\
& \text { DMT-004 : Karena ini disini ada } 2 \text { variabel yaitu tahun pertama dan } \\
& \text { keuntungannya } \\
& P-005 \quad \text { : Kenapa yang kita tulis itu } 1 \text { sama 3? Kenapa bukan } 1998 \text { sama } \\
& \text { 2000? } \\
& \text { Karena ini pemisalannya yaitu tahun pertama kemudian tahun } \\
& \text { DMT-005 : ketiga, dan penghasilan tahun pertama yaitu } 3 \text { miliar rupiah dan } \\
& \text { pengasilan pada tahun ketiga yaitu } 25 \text { miliar rupiah. }
\end{aligned}
$$

Pada Transkrip 1, siswa DMT mengatakan bahwa untuk menyelesaikan soal digunakan rumus persamaan garis lurus yaitu : $\frac{y-y_{1}}{y_{2}-y_{1}}=\frac{x-x_{1}}{x_{2}-x_{1}}$ (DMT-003), dengan alasan terdapat dua variabel yang dapat diketahui dari soal yaitu tahun dan keuntungan (DMT-004). Adapun, data yang siswa DMT ketahui dari soal yaitu tahun pertama dengan penghasilan 3 miliar dan tahun ketiga dengan penghasilan 25 miliar (DMT-005). Selanjutnya, siswa DMT menjelaskan prosedur penyelesaian secara bertahap dan dengan alasan yang tepat. Selain prosedur penyelesaian, siswa DMT juga menyebutkan informasi yang terdapat pada soal yang tidak dituliskannya pada 
lembar jawaban. Informasi yang dimaksud berupa hal yang diketahui dan ditanyakan. Hal tersebut menandakan bahwa siswa juga mampu memahami soal dengan baik. Dengan demikian, siswa DMT dikatakan mampu memahami dan menuliskan prosedur penyelesaian dengan tepat.

2. Menjelaskan solusi dalam bentuk gambar

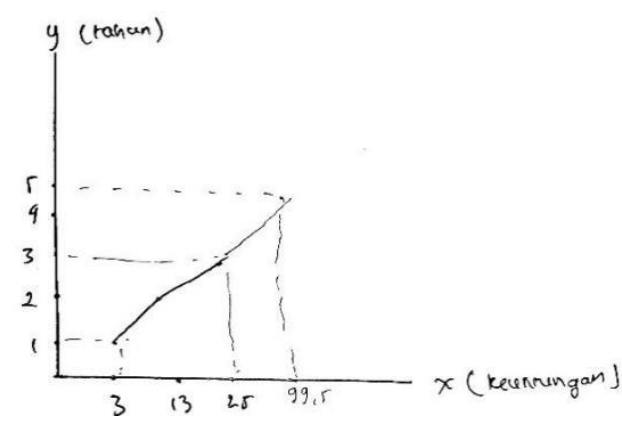

GAMBAR 2 Hasil tes siswa DMT

Pada Gambar 2, terlihat bahwa grafik yang digambarkan oleh siswa DMT berupa grafik garis lurus. Pada grafik tersebut, siswa DMT menyatakan koordinat-x sebagai keuntungan, dan koordinat-y sebagai tahun. Grafik yang digambarkan merupakan hasil dari menghubungkan 3 titik. Ketiga titik yang digunakan siswa untuk membuat garis yaitu $(3,1),(25,3)$ dan $(99.5,5)$. Selain itu, siswa DMT menggunakan garis putus-putus pada koordinat $\mathrm{x}$ dan koordinat y untuk menunjukkan letak titik yang digunakan untuk membuat grafik. Penjelasan siswa terkait grafik dapat dilihat pada Transkrip 2.

\section{TRANSKRIP 2}

$P-020 \quad$ : Mm terakhir bagian b grafik, mengenai grafik ini coba jelaskan?

DMT-020 . Grafikkan dengan $x$ dan y eee $x$-nya saya ambil keuntungan

$P-021 \quad: \quad$ Iyah, terus?

Nah, untuk tahun pertama saya gunakan titik pada tahun pertama

dan keuntungannya yaitu 3 miliar. Kemudian untuk yang kedua

DMT-021 : saya gunakan pada tahun ketiga dengan keuntungannya itu 25

miliar rupiah. Dan pada titik ketiga yaitu setelah 5 tahun 2 bulan

dengan keuntungan 99,5 miliar rupiah.

$P-022 \quad$ : Terus, apa yang perlu diperhatikan dalam buat grafik?

DMT-022 : Eeeh datanya, data yang telah diperoleh. Dengan penempatan titik itu harus tepat.

Berdasarkan Transkrip 2, siswa DMT menyebutkan bahwa grafik digambarkan dengan koordinat-x yang dinyatakan sebagai keuntungan dan koordinat-y sebagai tahun (DMT-020). Selanjutnya, siswa DMT menyebutkan 3 titik yang digunakan untuk menggambarkan grafik yaitu $(3,1),(25,3)$ yang digunakan merupakan hal yang diketahui dari soal, dan satu titik lainnya yaitu $(99.5,5)$ diperoleh dari hasil penyelesaian (DMT-021). Selanjutnya, penempatan titik pada bidang kartesius yang dilanjutkan dengan menghubungkan titik-titik tersebut untuk memperoleh grafik persamaan garis lurus. Selain itu, siswa DMT juga mengatakan bahwa selain data, dalam pembuatan grafik perlu pula diperhatikan penempatan titik yang tepat (DMT-022). Dengan demikian, siswa DMT dikatakan mampu memberikan penjelasan jawaban yang berupa gambar/grafik.

3. Menggunakan simbol matematika yang tepat

Pada lembar jawaban yang dituliskan oleh siswa, simbol yang digunakan untuk menuliskan penyelesaian berupa variabel-x dan variabel-y. Diketahui siswa menyatakan variabel $x$ sebagai keuntungan dan variabel $y$ sebagai tahun. Hal ini menjelaskan bahwa siswa konsisten dengan penggunaan variabel untuk menyelesaikan seluruh permasalahan. Selain itu, tidak terdapat 
kekeliruan substitusi data pada masing-masing variabel pada penyelesaian yang siswa tulis. Dengan demikian, siswa DMT dikatakan mampu menggunakan simbol dengan tepat.

\section{Siswa dengan disposisi matematis sedang (DMS)}

Berikut disajikan hasil tes dan wawancara siswa DMS yang didasarkan pada indikator-indikator kemampuan komunikasi matematis siswa.

1. Memahami dan menuliskan solusi permasalahan

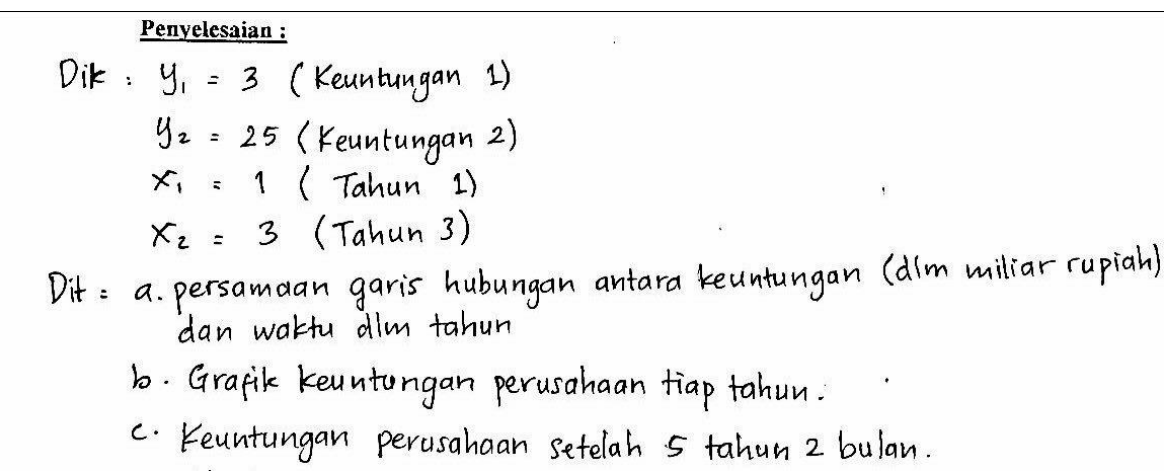

\section{GAMBAR 3 Hasil tes siswa DMS}

Pada Gambar 3 siswa menuliskan hal yang diketahui dari soal dan hal yang ditanyakan pada soal. Siswa menggunakan variabel untuk menyatakan data atau informasi yang siswa ketahui dari soal. Siswa menuliskan 2 variabel yaitu variabel $x$ dan variabel $y$ yang masing-masing terdiri dari 2 data yaitu 1 dan 3 , serta 3 dan 25 . Data tersebut merupakan data yang siswa ketahui dari soal. Selanjutnya, siswa menuliskan penyelesaian seperti pada Gambar 4 dengan menggunakan informasi pada Gambar 3.

$$
\text { Peny: a. } \begin{aligned}
\frac{y-y_{1}}{y_{2}-y_{1}} & =\frac{x-x_{1}}{x_{2}-x_{1}} \Rightarrow \frac{y-3}{25-3}=\frac{x-1}{3-1} \\
=\frac{y-3}{22} & =\frac{x-1}{2} \Rightarrow 2(y-3)=22(x-1) \\
=2 y-6 & =22 x-22 \\
2 y & =22 x-22+6 \\
2 y & =22 x-16 \\
y & =11 x-8
\end{aligned}
$$

GAMBAR 4 Hasil tes siswa DMS

Gambar 4 menunjukkan langkah awal yang siswa lakukan yaitu menggunakan rumus $\frac{y-y_{1}}{y_{2}-y_{1}}=$ $\frac{x-x_{1}}{x_{2}-x_{1}}$ untuk mencari persamaan garis lurus. Selanjutnya, siswa mensubstitusi data yang diketahui pada Gambar 3 ke rumus. Langkah-langkah selanjutnya yang dituliskan siswa lengkap dan tidak terdapat kesalahan substitusi maupun perhitungan. Pada saat wawancara, siswa juga mampu menjelaskan setiap tahapan dan dengan alasan yang tepat. Berdasarkan hal tersebut, diketahui bahwa siswa DMS mampu memahami dan menuliskan solusi dengan tepat. 
2. Menjelaskan solusi dalam bentuk gambar

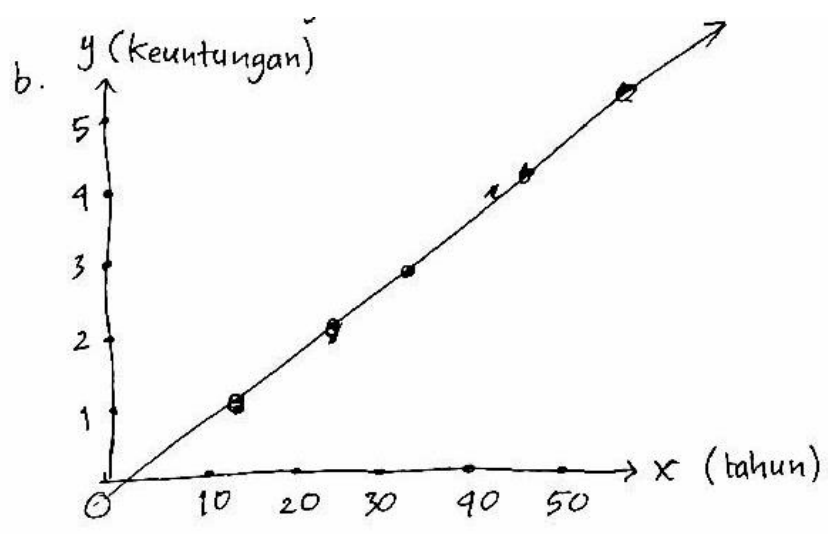

GAMBAR 5 Hasil tes siswa DMS

Gambar 5 menunjukkan grafik yang digambarkan oleh siswa DMS berupa garis lurus. Pada grafik tersebut, siswa menyatakan koordinat-x sebagai tahun dan koordinat-y sebagai keuntungan. Hal tersebut sesuai dengan pemisalan yang dituliskan siswa pada Gambar 3. Grafik tersebut terdiri dari 5 titik yang dihubungkan. Siswa tidak menggambarkan garis bantu yang menyatakan setiap titik sehingga tidak dapat diketahui titik-titik yang digunakan oleh siswa melalui Gambar 5. Penjelasan siswa terkait grafik yang digambarkannya dapat dilihat pada Transkrip 3.

\section{TRANSKRIP 3}

$P-015 \quad: \quad$ Terus, bagaimana caranya dapat titik-titiknya?

DMS - $015 \quad$ Eeeh, karena persamaannya tadi $y=11 x-8$ langsungmi saja $1 y$

: $\quad$ langsungmi saja di kasi anu di $11 x-8$ (sambil menunjuk). Ndak tauka bagaimana kurang 8nya kak.

$P-016 \quad: \quad B e g i t u$ semua ini yang titik-titiknya?

$D M S-016 \quad:$ Iye

$P-017 \quad:$ Kalau sudahnya di dapat, diapakan?

DMS-017 : Disambung dan di bentuk garis lurus

Berdasarkan Transkrip 3 diketahui dalam menggambarkan grafik, siswa mengggunakan persamaan $y=11 x-8$ untuk menentukan data (DMS-015). Setelah menentukan beberapa data (titik), selanjutnya siswa menghubungkan titik-titik tersebut dan membentuk grafik berupa garis lurus (DMS-017). Namun, grafik yang digambarkan kurang tepat karena siswa melakukan kesalahan dalam proses penentuan data (titik). Proses penentuan titik yang dilakukan siswa tidak berdasarkan proses substitusi data ke persamaan. Melainkan, siswa hanya memperhatikan koefisien setiap variabel dari persamaan dan tidak melibatkan konstanta ' -8 ' dalam penentuan titik. Adapun titik lain yang digunakan hanya merupakan kelipatan dari titik awal yaitu $(11,1)$ yang telah siswa tentukan (DMS-016). Berdasarkan hal tersebut, diketahui bahwa siswa DMS kurang mampu dalam memberikan dan menjelaskan jawaban berupa gambar/grafik.

3. Menggunakan simbol matematika yang tepat

Penyelesaian yang dituliskan oleh siswa menggunakan simbol matematika berupa variabel. Variabel yang digunakan yaitu variabel $x$ yang menyatakan tahun dan variabel $y$ yang menyatakan keuntungan. Hal ini menjelaskan bahwa siswa konsisten dengan penggunaan variabel untuk menyelesaikan seluruh pertanyaan. Selain itu, siswa tidak melakukan kekeliruan pada proses substitusi data ke masing-masing variabel. Berdasarkan hal tersebut, diketahui bahwa siswa DMS mampu menggunakan simbol matematika dengan tepat. 


\section{Siswa dengan disposisi matematis rendah (DMR)}

Berikut disajikan hasil tes dan wawancara siswa DMR yang didasarkan pada indikator-indikator kemampuan komunikasi matematis siswa.

1. Memahami dan menuliskan solusi permasalahan

$$
\begin{aligned}
& \text { Penvelesaian: } \\
& \frac{9)}{y_{2}-y_{1}}=\frac{x-x i}{2-x i} \\
& y-3=\frac{x-61998}{2000-1998} \\
& 25-3=x-1998 \\
& \frac{y-3}{22}=\frac{x}{2} \\
& \begin{array}{l}
33(y-3)=22(x-1998) \\
2 y \cdot=22 x-43956 * 6
\end{array} \\
& 2 y: \frac{22 x-43950-79: 110 x-21975}{2}
\end{aligned}
$$

GAMBAR 6 Hasil tes siswa DMR

Pada Gambar 6, terlihat siswa menggunakan rumus $\frac{y-y_{1}}{y_{2}-y_{1}}=\frac{x-x_{1}}{x_{2}-x_{1}}$ untuk menentukan persamaan garis lurus. Selanjutnya, siswa melakukan proses substitusi data ke variabel $x_{1}, x_{2}, y_{1}$, dan $y_{2}$ pada rumus. Data yang disubstitusikan pada setiap variabel yaitu 2000, 1998, 25, dan 3. Selanjutnya, siswa menuliskan langkah-langkah penyelesain dengan lengkap sehingga memperoleh persamaan $y=11 x-21975$. Persamaan tersebut kurang tepat karena terdapat kesalahan dalam pensubstitusian data tepatnya pada variabel $x$. Dengan demikian, siswa DMR diketahui kurang mampu memahami dan menuslikan solusi dengan tepat.

2. Menjelaskan solusi dalam bentuk gambar

Pada lembar jawaban tes, siswa tidak menggambarkan grafik persamaan garis lurus. Berikut penjelasan siswa.

\section{TRANSKRIP 4}

$P-014 \quad: \quad$ Kenapa ndak kita jawab bagian b?

DMR-014 : Yang bagian b sama c kurang paham sama soalnya kak.

$P-015 \quad: \quad$ Masih kita ingat bagaimana caranya gambar grafik?

DMR-015 : Masih, yang kalau koordinator biasa

$P-016 \quad: \quad$ Kalau menurutta bagaimana tentukan titik-titik grafiknya?

DMR-016 : Ee.. anu, berpatokan sama $x$ dan y

Pada Transkrip 4 terlihat bahwa siswa mengaku kurang paham sehingga tidak menggambarkan grafik persamaan garis lurus (DMR-014). Siswa mengaku masih mengingat proses penggambaran grafik (DMS-015). Siswa menyebutkan bahwa penentuan titik grafik berpatokan pada $x$ dan $y$ (DMR-016). Hal ini menjelaskan bahwa siswa memberikan jawaban dengan menerka-nerka. Siswa tidak mengetahui langkah-langkah yang dilakukan untuk menggambarkan grafik. Dengan demikian, siswa DMR diketahui tidak mampu untuk memberikan solusi berupa gambar/grafik. 
3. Menggunakan simbol matematika yang tepat

Pada Gambar 6 diketahui siswa menggunakan simbol berupa variabel dalam menuliskan solusi permasalahan. Variabel yang digunakan yaitu variabel $x$ yang menyatakan tahun dan variabel $y$ yang menyatakan keuntungan. Siswa tidak melakukan kekeliruan pada proses substitusi data ke masing-masing variabel. Dengan demikian, siswa DMR diketahui mampu menggunakan simbol matematika dengan tepat.

\section{KESIMPULAN}

Kemampuan komunikasi matematis setiap siswa berbeda berdasarkan tingkat disposisi matematis. Seluruh siswa pada setiap tingkatan disposisi, mampu menuliskan solusi yang lengkap secara sistematis. Namun, siswa dengan disposisi matematis rendah kurang mampu memahami masalah sehingga terdapat kekeliruan dalam proses menuliskan solusi. Selain itu, seluruh siswa mampu menuliskan penyelesaian menggunakan simbol matematika yang tepat berupa variabel. Penggunaan variabel yaitu variabel $\mathrm{x}$ dan variabel y dalam penulisan solusi dilakukan karena seluruh siswa sudah terbiasa menggunakan variabel tersebut untuk menyelesaikan soal matematika. Perbedaan kemampuan komunikasi matematis setiap siswa terlihat dari kemampuan menggambarkan grafik solusi. Siswa dengan disposisi matematis tinggi mampu menggambarkan grafik yang tepat dan memberikan penjelasan dengan alasan yang tepat. Siswa dengan disposisi matematis sedang kurang mampu menggambarkan grafik dengan tepat dan kurang mampu memberikan penjelasan mengenai grafik. Sedangkan, siswa dengan dipsosisi matematis rendah tidak mampu menuliskan jawaban berupa grafik.

\section{DAFTAR PUSTAKA}

Andiani, D. (2016). Meningkatkan Kemampuan Representasi, Disposisi Matematis Melalui Pembelajaran Berbasis Masalah Teknik Mind Map. Pasundan Journal of Mathematics Education (PJME), 2. 48-60.

Afiani, N. (2016). Pengaruh Kemampuan Komunikasi Matematis dan Kemandirian Belajar Terhadap Prestasi Belajar Matematika. Jurnal Kajian Pendidikan Matematika, 2 (1). 113.

Annajmi. (2018). Kontribusi Disposisi Matematis terhadap Prestasi Belajar Matematika Siswa Kelas VIII SMPN 3 Tambusai. Edumatica, 8 (1). 1-8.

Astuti, A., \& Leonard. (2012). Peran Kemampuan Komunikasi Matematika Terhadap Prestasi Belajar Matematika Siswa. Jurnal Formatif, 2. (2).

Bistari, B. S. (2010). Pengembangan Kemandirian Belajar Berbasis Nilai Untuk Meningkatkan Komunikasi Matematik. Jurnal Pendidikan Matematika dan IPA, 1 (1). 11-23.

Diningrum, P. R., Azhar, E., \& Faradillah, A. (2018). Hubungan Disposisi Matematis Terhadap Kemampuan Komunikasi Matematis Siswa Kelas VII SMP Negeri 24 Jakarta. Seminar Nasional Pendidikan Matematika.

Hikmawati, N. N., Nurcahyono, N. A., \& Balkist, P. S. (2019). Kemampuan Komunikasi Matematis dalam Menyelesaikan Soal Geometri Kubus dan Balok. Jurnal PRISMA, 8 (1). 68-79.

Hodiyanto. (2017). Kemampuan Komunikasi Matematis dalam Pembelajaran Matematika. Jurnal AdMathEdu, 7 (1). 9 - 17.

Mahmudi, A. (2010). Tinjauan Asosiasi antara Kemampuan Pemecahan Masalah Matematis dan Disposisi Matematis. Seminar Nasional Pendidikan Matematika. Yogyakarta, Indonesia: Universitas Negeri Yogyakarta. 
Mandur, K., Sadra, I.W., \& Suparta, I.N. (2013). Kontribusi kemampuan koneksi, kemampuan representasi, dan disposisi matematis terhadap prestasi belajar matematika siswa SMA Swasta di Kabupaten Manggarai. E-Journal Proggram Pascasarjana Universitas Pendidikan Ganesha, 2.

National Council of Teachers of Mathematics (NCTM). (2000). Principles and Standards for School Mathematics.

Nurhaja \& Suhar. (2015). Pengaruh Disposisi Matematik dan Dukungan Sosial Terhadap Prestasi Belajar Matematika Siswa SMA Negeri 7 dan SMA Negeri 9 Kendari. Jurnal Penelitian Pendidikan Matematika, 3 (1). 107-120.

Ocktaviani, N. N., Aulia, S. N., \& Zanthy. L.S. (2019). Pengaruh Kemampuan Komunikasi Matematis dan Minat Belajar Terhadap Prestasi Belajar Matematika. Juurnal Pendidikan Matematika Inovatif, 2 (4). 161-166.

Peraturan Menteri Nomor 58 tentang Kurikulum 2013 SMP. (2013). Menteri Pendidikan dan Kebudayaan Republik Indonesia.

Simamora, R. (2017). Implementasi Kurikulum 2013 Terhadap Kemampuan Komunikasi Matematika Siswa Pada Materi Program Linear Di Kelas XI SMA Negeri 2 Pematangsiangtar TA 2016/2017. Journal of Mathematics Education and Science, 2 (2). 59-69.

Sumarmo, U. (2011). Berfikir dan Disposisi Matematik: Apa, Mengapa dan Bagaimana Dikembangkan Pada Peserta Didik. Tersedia dalam https://www.academia.edu/10346582/BERFIKIR_DAN_DISPOSISI_MATEMATIK_AP A_MENGAPA_DAN_BAGAIMANA_DIKEMBANGKAN_PADA_PESERTA_DIDIK diakses pada 5 Februari 2019.

Wijaya, H. P. I., Sujadi. I., \& Riyadi. (2016). Kemampuan Komunikasi Matematis Sesuai dengan Gender dalam Pemecahan Masalah Pada Materi Balok dan Kubus (Studi Kasus Pada Siswa SMP Kelas VIII SMP Islam Al-Azhar 29 Semarang. Jurnal Elektornik Pembelajaran Matematika, 4 (9). 778-788. 